\title{
11 Family firms and regional development
}

\author{
Evidence from China
}

\author{
Xinrui Zhang, Junsheng Dou and Hanqing \\ "Chevy" Fang
}

\section{Introduction}

In recent years family business literature has started recognizing the importance of context (Gomez-Mejia, Basco, Müller, \& Gonzalez, 2020; Morck \& Steier, 2005) to better understand family firm behavior. This is because context might affect the size and structure of the business family, resource endowment, and feasible governance mechanisms that business families use to protect their economic and non-economic endowments (Chen, Fang, MacKenzie, Carter, Chen, \& Wu, 2018; De Massis, Ding, Kotlar, \& Wu, 2016; Janjuha-Jivraj \& Woods, 2002; La Porta, Lopez-de-Silanes, \& Shleifer, 1999).

Since opening up to global trade and implementing free-market reforms in 1978, China's economy has experienced tremendous growth, with a $9.5 \%$ average annual growth rate in gross domestic product (GDP). Indeed, China has grown from a low-income economy with a GDP per capita of less than $\$ 200$ to a middle-income country with about $\$ 8,800$ GDP per capita. Market reforms have also nurtured a large population of entrepreneurs, who have become the driving force behind the increasingly important private economic sector in China (Tsang, 1996). As China's economic system continues to mature, entrepreneurs who were able to capture the opportunities of the reform in the 1980s have reached an age where they need to consider the possibility of passing their business to next-generation family members (Pistrui, Huang, Oksoy, Jing, \& Welsch, 2001).

Nonetheless, most research in family business is contextless and scholars in this field have recognized that more studies are needed to better explore the interaction between family firms and context (James, Hadjielias, Guerrero, Discua Cruz \& Basco, 2020). At the same time, despite the strong interdependence among family businesses, business families, and the Chinese context, we still lack a thorough understanding of how the Chinese context might contribute to unique specificities of Chinese family firms. It is an emerging economy but at the same time is also a transitional one. Hence, federal and regional governments play an important role in designing policies that eventually impact how family firms behave and perform.

Our evidence shows that, just like in other economies, family firms are a relatively common phenomenon in China across regions. Additionally, we 
observe that even though there is a prevalence of family firms, its presence varies across geographical regions. Finally, our findings show that, comparable to other national and regional economies, Chinese regional development seems to have substantial effects on family firm behaviors in terms of R\&D investment, industrial diversification, and internationalization.

\section{The Chinese context, institutional transition, and family entrepreneurs}

Just like in other economies, family firms are highly prevalent in China, if not more so (Sharma \& Chua, 2013). Different from other cultural environments, business leadership in China is inextricably tied to the central role that family plays in business (Liden, 2012), largely stemming from the Confucian norms and values deeply embedded in Chinese society. In China, the idea of "family" (Chinese: 家) refers to a unit of members related to each other by blood, marriage, or adoption, characterized by culturally defined role differentiations and solidarity among members, the owning of common property, the sharing of common production and common consumption, as well as the practice of common social activities. Here, "family" would go beyond simply a biological unit bonded by marriage and blood. In fact, Chinese family can be conceptualized as a social unit in which family members' roles and solidarity relations are defined by underlying Confucian values; it is an economic unit in which living members produce and consume in common and also a cultural unit where the family is responsible for performing certain anthropological rituals such as ancestor worship for the wellbeing of both living and deceased members.

Note that, Confucian norm specify a unique relationship between the family and the individual. In the West, the family often serves the basic function of raising and preparing an individual before he/she goes out into the world and becomes a full member of society. As a result, families often experience a "break up" when children reach adulthood, depart from the original family, and start to build their own nuclear families. In other words, the family system in Western society exists to nurture junior family members. The situation in the traditional Chinese context is the exact opposite: the purpose of family members, especially junior males, is to nurture and continue the family, which is often aligned with a shared family surname, history, and antecedents. As Baker puts it,

There is an underlying assumption in Chinese thinking on the family that there is such a thing as a "Continuum of Descent"...Decedent is a unity, a rope which began somewhere back in the remote past, and which stretches on to the infinite future ... the individual alive is the personification of all his forebears and all his descendants yet unborn.

$(1979,26)$

Hence, it is not a surprise to see that Baker concluded that the "individual was dominated by the family (in China)" and "the actions of individuals were geared to the requirements of the (Chinese) family" $(1979,27)$. 
Given its prevalence and strong influence, the family-centered culture in China often makes family business the default form when entrepreneurs start their ventures (Aldrich \& Cliff, 2003). Also, family members are socially and culturally obligated to support each other's business initiatives and family-endowed financial, social, and human capital are often used in the family system (Arregle, Hitt, Sirmon, \& Very, 2007). In addition, business leaders in China are often considered "father figures", who are expected to have proven capability and integrity, yet be considerate, and are expected to take good care of even non-family managers and employees. Taken together, it appears reasonable to conclude that the prosperity and idiosyncrasies of Chinese family firms partially stem from traditional Confucian culture, which emphasizes the inseparable connection between the individual and the family system.

Besides informal institutions such as culture and value systems, formal institutions also play an important role. Indeed, China is still a transitional economy undergoing changes in its economic and political systems. The most relevant part for our discussion is the adolescence stage of the private sector, where economic activities led by entrepreneurs started during 1980s and 1990s (Pistrui, Huang, Oksoy, Jing, \& Welsch, 2001). Prior to this, China was a planned economy largely controlled by stateowned firms, with very few opportunities left to private enterprises. It is family entrepreneurs/founders who started the first wave of privately owned businesses immediately after the 1978 Open-Up and Reform era. In addition, given the fact that formal institutions such as the protection of property rights are still not fully developed in China, family governance is often used to "fill the voids". Here, the family's reputation often serves as a reliable substitution for effective commercial laws and the family network might help reduce the cost of searching for business partners and maintaining business relationships (i.e., transaction costs).

Finally, because of the emerging nature of Chinese economy, all family entrepreneurs and family firms in China are relatively young. In fact, in Western economies some family firms have already been successfully passed from the founding members to the second or later generations (Chua, Chrisman, \& Sharma, 2003; Morck \& Steier, 2005). In comparison, the majority of Chinese family firms have never experienced intra-family, trans-generational succession (Janjuha-Jivraj \& Woods, 2002). Furthermore, entrepreneurs and business families in China still lack experience with family governance as well as talent in the family labor pool (Morris, Allen, Kuratko, \& Brannon, 2010). Finally, the global economy has entered a period of recovery and China's economy, which had been on the rise so far, is facing a slowdown. In contrast to mature family firms in Western countries, which have already experienced various economic cycles ( $\mathrm{La}$ Porta, Lopez-de-Silanes, \& Shleifer, 1999), family firms in China are still struggling to leverage technological innovation and strategic renewal in order to maintain their positions in the market (De Massis, Frattini, \& Lichtenthaler, 2012; De Massis, Ding, Kotlar \& Wu, 2016). 
To summarize, meaningful insights of family business in China cannot be decoupled from (1) cultural heritage stemming from Confucian culture and values; (2) institutional transitions that are strongly connected with economic growth in China; and (3) family founders/entrepreneurs who started the business. In the following sections, we will discuss the specific characteristics of family entrepreneurs and family business, family governance, and strategic and environmental issues in family business. In our discussions, we will elaborate on the unique "Chinese characteristics" of family business in the country, which either result from or contribute to the nation's economic growth and institutional transitions.

\section{History and overview of Chinese family business}

\section{Data sources}

All the following discussions are based upon information from two data sources. The first is the China Stock Market \& Accounting Research Databases (CSMAR), which covers all publicly listed firms in China. In line with existing research (Chua, Chrisman, \& Sharma, 1999; La Porta et al., 1999), we classify family business as those with (1) at least 15\% family ownership and (2) at least two family members who currently serve as top managers and directors. The second data source is the All-China Federation of Industry and Commerce (ACFIC) database, which is based on a survey effort of private enterprises in China from 1995 to 2016, with data collected once every two years. We also include a data collection on the "health and sustainability of Chinese family firms" jointly conducted by Zhejiang University and the All-China Federation of Industry and Commerce in 2015 and 2016. The nature of public and private family firms vary due to firm size and goals that the dominant coalition pursues. Therefore, we used data from public and private family firms and we separated the analysis because both types may differ in terms of behavior and performance.

Furthermore, according to the China market index, we classify provinces and areas in China into three categories: highly-developed, moderatelydeveloped, and under-developed. In general, most provinces along the eastern and southern coast fall into the highly developed category. Provinces in the middle and mid-western parts of China are mostly moderately developed, whereas those in the west or south-western parts are under-developed. This observation is consistent with the idea that the coastal areas are more likely to be exposed to economic opportunities, hence more likely to experience higher economic development.

In the following sections, we draw attention to regional differences with regard to family firm behavior, structure, and performance. Such an effort reflects our research intention of explaining the spatial distribution of Chinese family firms as well as their differences and similarities across regions. Additionally, when the data information allows, we will explore the regional influence on Chinese family business. 


\section{Xinrui Zhang et al.}

\section{Private enterprises and family business in China: an overview}

According to the National Bureau of Statistics of China, in 1996 there were 443,000 private enterprises. In 2017, the number reached 14.4 million with an increase of 31.4 times and an average annual growth rate of $18.0 \%$. The proportion of private enterprises increased from $16.9 \%$ to $79.4 \%$. In addition, as of 2017 private firms have contributed to more than $60 \%$ of China's GDP, $50 \%$ of national tax, $70 \%$ of investment in technological innovation and new product development, and $80 \%$ of newly created jobs. According to China's National Bureau of Statistics, the number of private enterprises in China has dramatically accelerated over the past few years (Figure 11.1). Among them, the number of private enterprises in highly-developed areas have been much higher than that in moderately-developed and under-developed areas. As shown in Figure 11.2, it appears that the level of regional economic

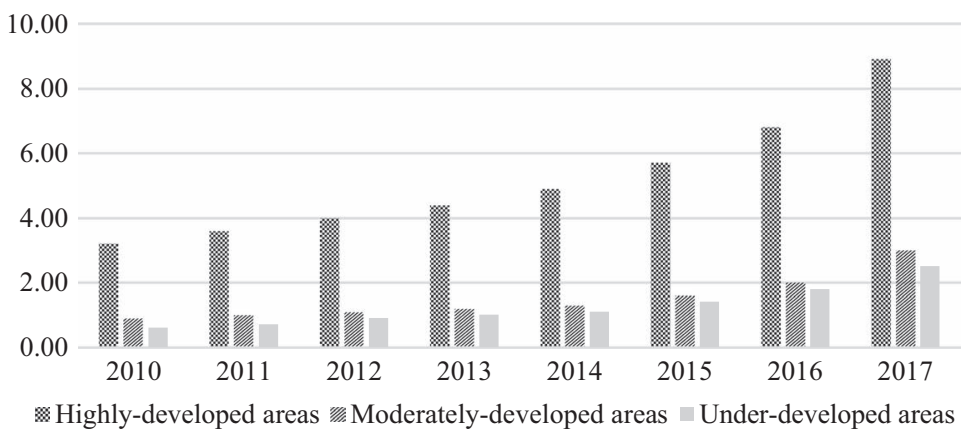

Figure 11.1 The number of private firm registration in China by regions (unit: million, 2010-2017).

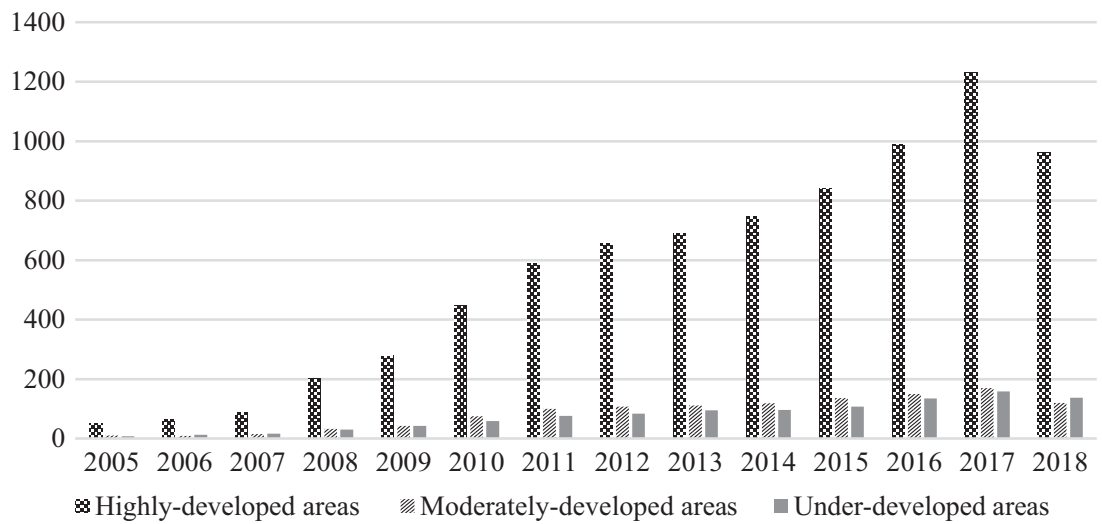

Figure 11.2 Publicly listed family firms in China and regional development (unit: million, 2005-2018). 


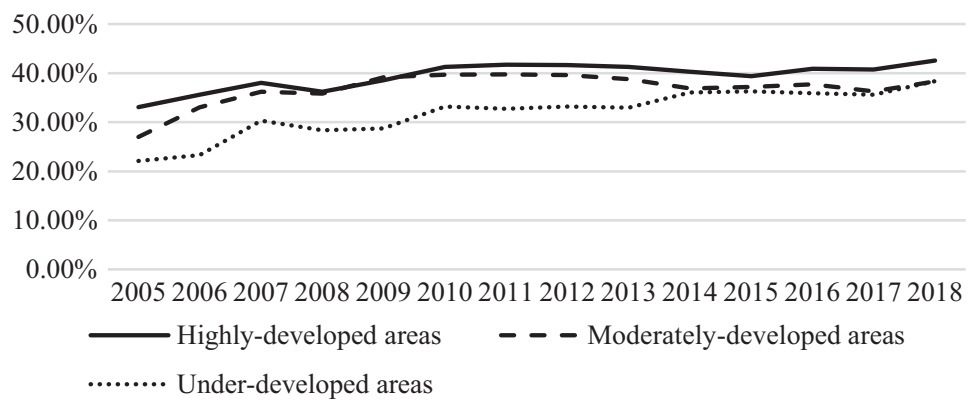

Figure 11.3 Average family ownership of Chinese listed firms.

development is positively associated with the number of private sectors/enterprises, especially family-owned ones.

In the following part we briefly discuss the general features of family involvement in ownership across publicicly-traded companies in China. According to the CSMAR database, average family ownership has increased over the past 14 years. Family ownership is highest in highly-developed areas, second in moderately-developed areas, and lowest in under-developed areas. However, the gap between moderately developed and underdeveloped areas has been narrowing in recent years, maybe because of the overall improvement of the institutional context across regions in China (Figure 11.3).

\section{Family entrepreneurs in China}

As mentioned above, any discussion on family firms in China cannot neglect the important role of family business leaders, who, in most cases, are the founders of the business. Yet, in contrast to their descendants, family entrepreneurs/founders might lack the formal knowledge, skills, and/or education to run the business, partially due to the under-developed educational system of China before the Opening-Up and Reform era. Nonetheless, in alignment with free-market reforms, education has become increasingly important and family entrepreneurs have been active in obtaining education in order to develop/maintain their competitive edges in the market. Indeed, ACFIC data from 1995 to 2016 shows that the education levels of family entrepreneurs have significantly improved over time (Figure 11.4).

Additionally, consistent with existing studies on family leadership in business (Chen et al., 2018), female family leaders have been on the rise. According to ACFIC data from 1995 to 2016, the proportion of female family leaders has increased from 10.40\% in 1995 to 20.40\% in 2016 (Figure 11.5). Such a change has also been observed in Western economies, which might reflect a global trend where the function of female family members has 


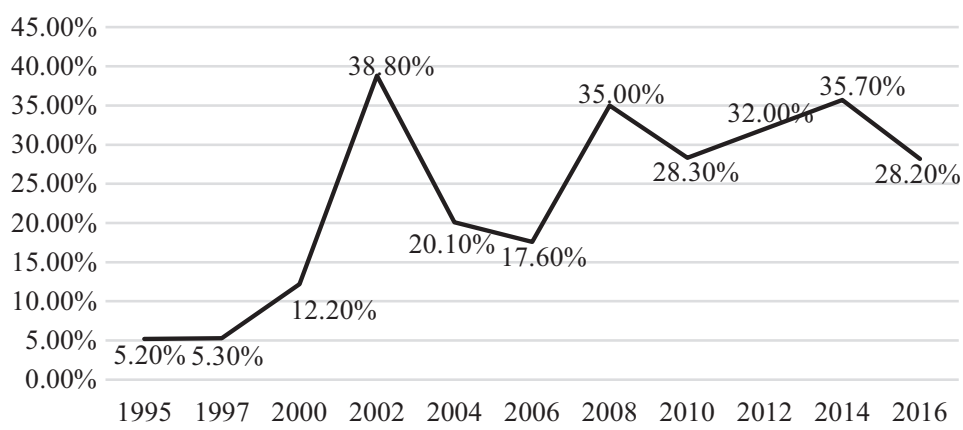

Figure 11.4 The proportion of Chinese entrepreneurs with bachelor's degree or above.

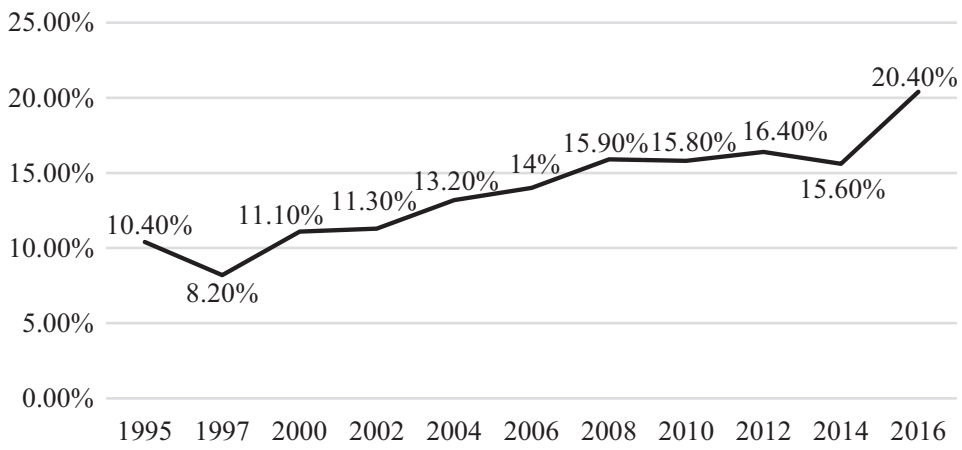

Figure 11.5 Proportion of female entrepreneurs in China.

transitioned from a supportive role in the family system into a leading role in the intersection between the family and business systems (Curimbaba, 2002; Nelton, 1998).

In the absence of a mature market system, family entrepreneurs in China often choose to develop political connections and/or join political alliances to better exploit opportunities and absorb uncertainties stemming from the context (Morck \& Yeung, 2004). In fact, business families' active political participation (the communist party) might facilitate access to valuable opportunities and resources, help overcome the liability of "newness" and lack of legitimacy in entrepreneurial activities, and potentially expand formal and informal networks (Tsang, 1996; N. Xu, X. Xu, \& Yuan, 2013). Indeed, according to the ACFIC survey, the proportion of family entrepreneurs with membership in the Communist Party of China (CPC) increased dramatically from the 1990s to early 2000 (Figure 11.6). Nonetheless, we 


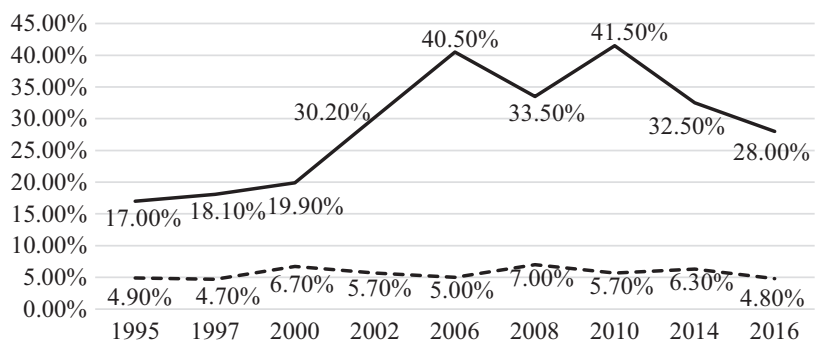

- The proportion of CPC ---- The proportion of other parties

Figure 11.6 Political background of entrepreneurs.

Note: CPC is short for Communist Party of China.

also observe strong fluctuations and the proportion has started to decline in recent years.

Due to data limitations we were unable to specify the variation of family private entrepreneurs across regions. Future researchers might want to collect additional data to explore these differences and causes, and how they might vary across regions.

\section{Current status}

This section intends to discuss critical issues related to current challenges in Chinese family business. The topics cover governance mechanisms, innovation, diversification, internationalization, and firm performance in Chinese family firms across regions.

\section{Corporate governance}

Just like their Western counterparts, Chinese business families are inclined to use governance mechanisms in enhancing their control over the business. Certain mechanisms such as a board of directors and chair positions are often used. These not only help the owning family supervise and control operational activities, but also mitigate the tension of conflicts of interest among shareholders and stakeholders and may help maximize the value of the firm in the longrun (Carney, 1998, 2005; Chrisman, Chua, Kellermanns \& Chang, 2007).

Starting from 1995, the percentage of family firms establishing boards of directors, boards of supervisors, and shareholder meetings has been increasing (Figure 11.7). According to the ACFIC survey, from 1995 to 2016 this trend can be best described as a "rise and fall". In 1995 only $29 \%$ of respondents had a board of directors. This number jumped to $74 \%$ in 2004 , and then declined into $43 \%$ in 2016. Similar trends have also been observed in the establishment of board of supervisors and shareholder meetings. 


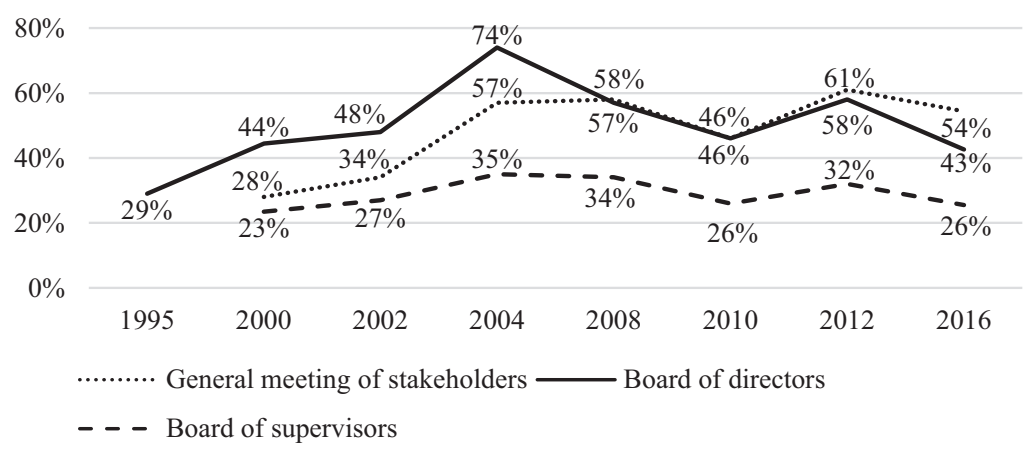

Figure 11.7 The governance institutions of Chinese private firms.

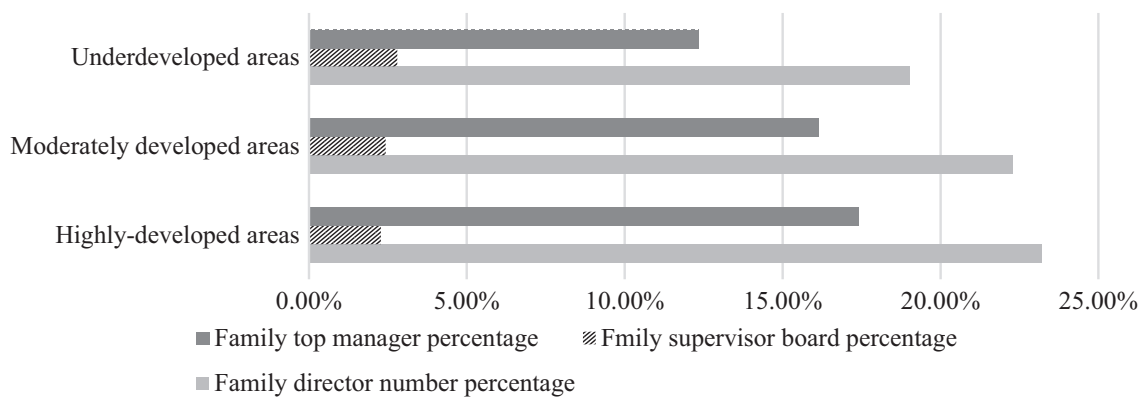

Figure 11.8 Family members in top management teams, supervisor boards and director boards by regions.

Nonetheless, executive, supervisory, and director positions are often reserved for family business founders or their relatives (Figure 11.8). In fact, the proportion of family members in the executive team (10-20\%) and the board of directors (15-25\%) are relatively high.

We notice substantial regional differences. In the more developed areas, we tend to have higher proportion of family members in the executive team and boards. This phenomenon may be due to the positive correlation between family ownership and regional development (Figure 11.3), as higher family ownership might motivate the family to assign more members to leadership positions. This might also stem from the improved education and capabilities of family members in highly-developed regions, hence making them more capable of management. Future researchers might want to collect additional data to explore these possibilities.

\section{Innovation}

Innovation is the driving force behind business growth and superior performance. Research and development (R\&D) intensity, measured as the R\&D 
expenditures/Sales percentage, is often used to capture a firm's resource investment in technology innovation. According to the European Union standard, firms with more than $5 \% \mathrm{R} \& \mathrm{D}$ intensity are considered to have a high level of R\&D investment, with 2-5\% a medium-level, and those below 2\% a low-level.

Using the CSMAR database, we track R\&D investment in 307 listed Chinese family firms from 2009 to 2015 . In general, half of them have an R\&D intensity between $2 \%$ and $5 \% ; 15.72 \%$ have an R\&D investment intensity higher than $5 \%$; and $21.21 \%$ below $1 \%$. In addition, firms whose founders are aged 41 to 50 have the highest level of R\&D in business (4.01\%). Also, family founders who have at least a bachelor's degree tend to invest more in their businesses compared to those with lower levels of education. In addition, family firms with both family owners and family managers have slightly higher R\&D intensity (3.69\%) compared to those with family involvement only in ownership (2.82\%). Furthermore, those with second or later family generation members in top management positions have higher R\&D investment compared to those without.

Note that the abovementioned findings are somehow different from the Western experience. As Fang et al. (2018) and Memili, Fang, and Welsh (2015) show, compared to the founding generation, second- or later-generation members in Western family firms are often more risk averse, reflected in lower levels of R\&D investment and internationalization. Our findings might imply that the transitional nature of the institutional and economic context in China, coupled with better overseas education among junior family members, might motivate late generation-controlled family firms to be more innovative and risk-taking compared to the founding generation-controlled family firms.

It appears that there is a positive correlation between a family firm's R\&D investment and regional development as those in developed regions tend to have higher R\&D investments (Figure 11.9). Such a phenomenon might be due to the prevalence of institutional voids in under-developed regions. Hence, family firms in these areas might be more motivated to invest resources in political connections rather than R\&D and technology innovation (Morck \& Yeung, 2004). It is also possible that under-developed areas

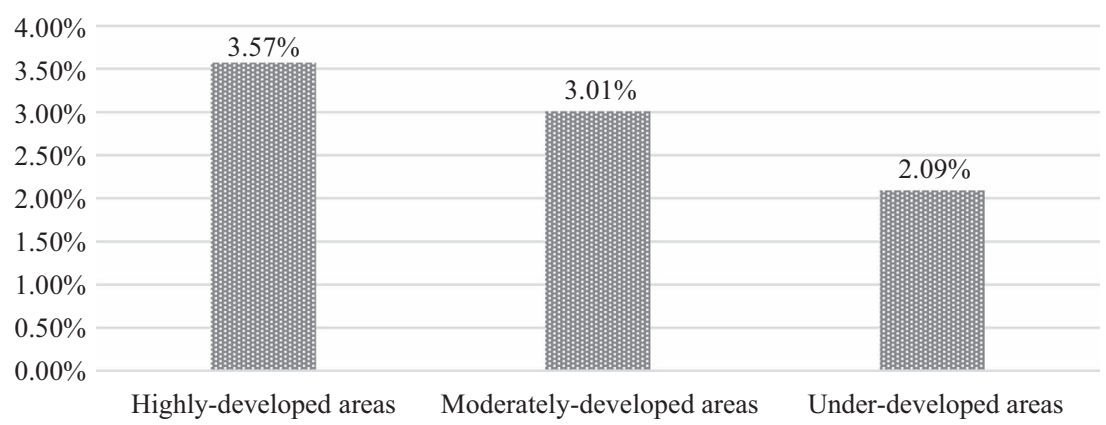

Figure 11.9 R\&D investment intensity of listed family firms in China by regions. 


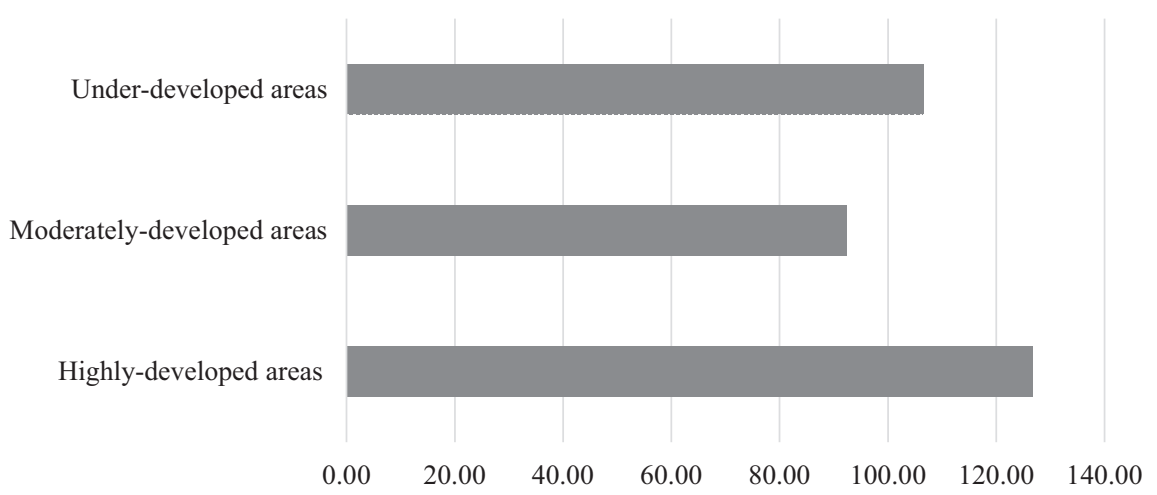

Figure 11.10 Average patens and invention patents of listed family firms in China by regions.

are dominated by low-technology industries and that the demand for R\&D is not urgent. In addition, such a finding might be due to the fewer colleges and universities, as well as the lack of supportive government policies, in under-developed regions. While we are unable to test these propositions given the data limitation, future studies may certainly further explore the specific mechanisms behind these differences.

It has been found that the number of patents in highly-developed areas is the highest, while those in moderately developed areas are the lowest (Figure 11.10). Given the fact that a patent is an outcome measure of innovation, this result might suggest that family firms vary in terms of innovation productivity across regions. Future researchers might want to pay more attention to this possibility.

\section{Diversification}

Diversification happens when the company expands its product lines and/ or enters a new geographic/industrial market. According to the CSMAR database, for 305 listed Chinese family firms from 2009 to 2015, the overall diversification index was 0.237 , a moderate level of diversification. Its calculation takes into account the number of different products, the distribution of products in the production line, and the dissimilarity or heterogeneity of products, applying equally well to plants/firms/industries and bounded between zero and unity (Gollop \& Monahan, 1991; Jacquemin \& Berry, 1979). Data from the United States in 1982 shows that the diversification index is between 0.049 and 0.482 (Gollop \& Monahan, 1991).

The proportion of non-related diversification is over $78 \%$, meaning that Chinese family firms tend to focus on market areas that are less related to 
their "core" business. Unrelated diversification can help neutralize risks from same business areas, but may also increase the cost of resource allocation and operational coordination (Jones \& Hill, 1988). It is our belief that the reason behind this unrelated diversification choice is the rapid growth of China's economy, which may create many new yet unrelated opportunities that business families intend to exploit. Additionally, unrelated diversification may be influenced by political connections (Faccio, 2006). A series of studies find that political connections might result in better firm performances in emerging economies (Li \& Zhang, 2007; Peng \& Luo, 2000). This is because when market and political institutions are immature, political connections can help companies better seek help from the government and obtain valuable resources such as financial support, novel technology, and monopoly permits (Peng, Lee, \& Wang, 2005). Furthermore, political connections are not bound to specific industries, hence this encourages companies to enter new industries to avoid idle resources (Li, He, Lan, \& Yiu, 2011).

There are also notable regional differences. Family firms in underdeveloped and highly-developed areas tend to have higher diversification compared to those in moderately developed regions (see Figure 11.11). One possible explanation is that family firms in highly-developed areas choose to diversify due to acquisition and leveraging of superior knowledge stemming from regional development. Conversely, family firms in underdeveloped areas diversify into certain industries that are not developed yet in order to exploit the first-mover advantage. In other words, in highlydeveloped regions, family firm diversification is driven by the "supply" side (capable of diversifying), while in under-developed regions it is driven by the "demand" side (the industry is emerging or has not been exploited yet).

In addition, different types of family involvement may affect the degree of business diversification. In fact, family involvement in both ownership and management is coupled with lower level of diversification compared to cases where families only serve as the owner (Figure 11.12).

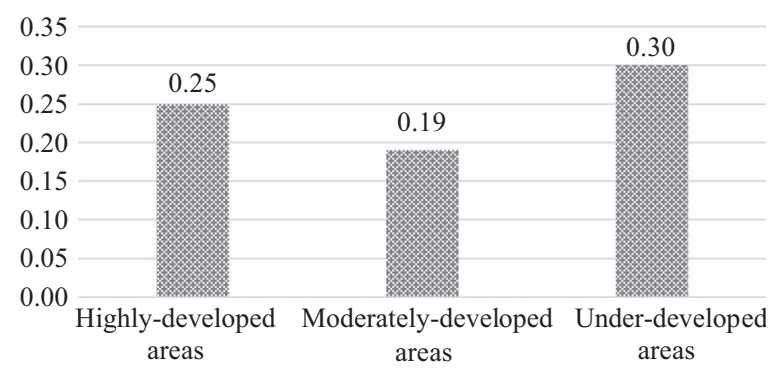

Figure 11.11 The degree of diversification of family businesses in different regions. 


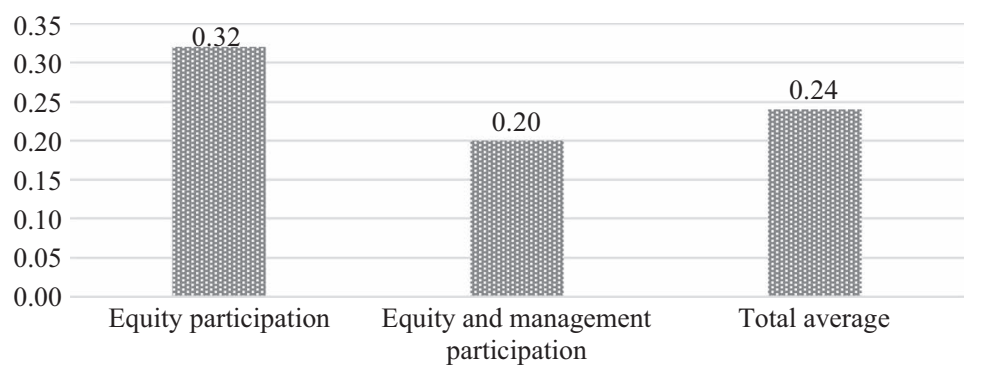

Figure 11.12 Types of family participation in business and enterprise diversification.

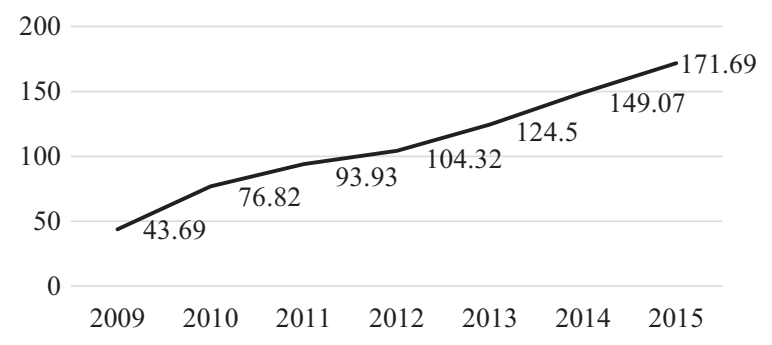

Figure 11.13 Total overseas business revenue of listed family enterprises in China (billion yuan).

Due to data limitations, we were unable to specify the particular causes of family firm diversification across regions. Future studies might explore the relationship between types of family participation in business, business diversification, and regional contexts.

\section{Internationalization}

Internationalization refers to a strategic choice in which companies expand the business territory into foreign countries. According to the CASMR database, from 2009 to 2015 there were, in total, 2,053 firm-year observations for publicly listed family firms in China. Among them, about $74.9 \%(1,538)$ had revenue from internationalization, resulting in a total of 768.794 billion yuan (about $\$ 109.83$ billion).

As shown in Figure 11.13, the incomes of Chinese family businesses from foreign operations has been increasing over time. The total overseas revenue in 2015 was about four times higher compared to that in 2009. In terms of regional differences (Figure 11.14), it appears that family firms in highly developed regions tend to have higher incomes (547 million yuan/year) from internationalization compared to those in moderately-developed (310 million 


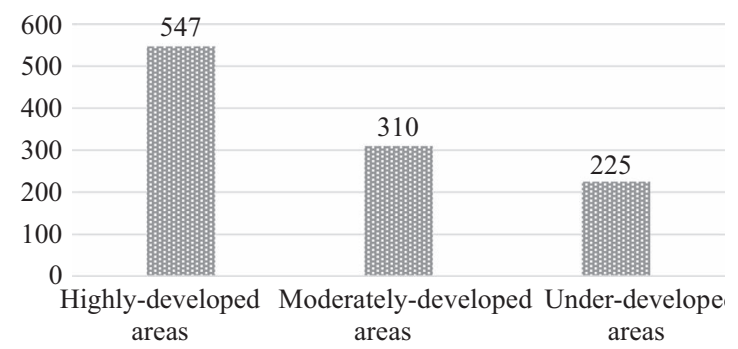

Figure 11.14 Overseas business revenue of family firms in different regions of China (billion yuan).

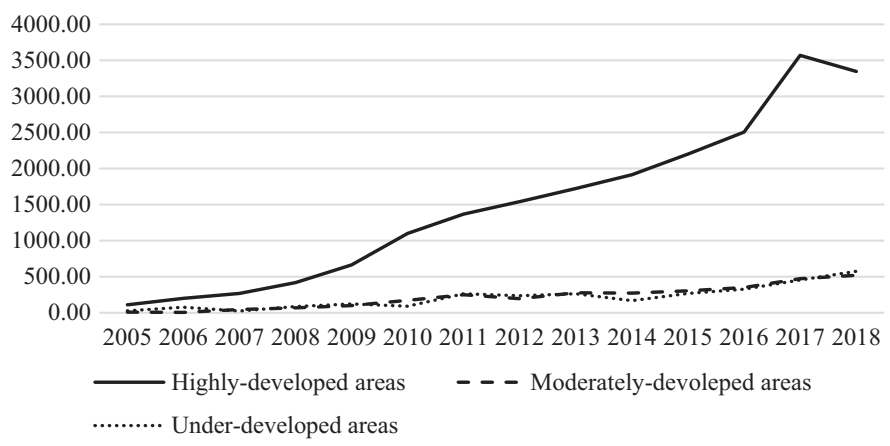

Figure 11.15 Annual sales of listed family firms by regions (billion yuan).

yuan/year) and under-developed (225 million yuan/year) areas. In China, highly-developed areas are located in coastal areas where geographical and transportation advantages may create more international opportunities. In addition, these regions might equip family members with better education and knowledge, which might help family firms benefit more from globalization. Finally, there might be more supportive government policies in highly-developed regions compared to others, stimulating more international activities in family firms. Indeed, future researchers might want to collect more data to explore the specific mechanisms behind our findings.

\section{Firm performance}

In the following analysis, we focus on two performance measures: sales and net profit. Figures 11.15 and 11.16 report change in sales and change in net profit in publicly traded family firms from 1999 to 2015. In general, family firms in China have experienced a state of dramatic growth in firm performance especially in highly-developed areas, which might be driven by 


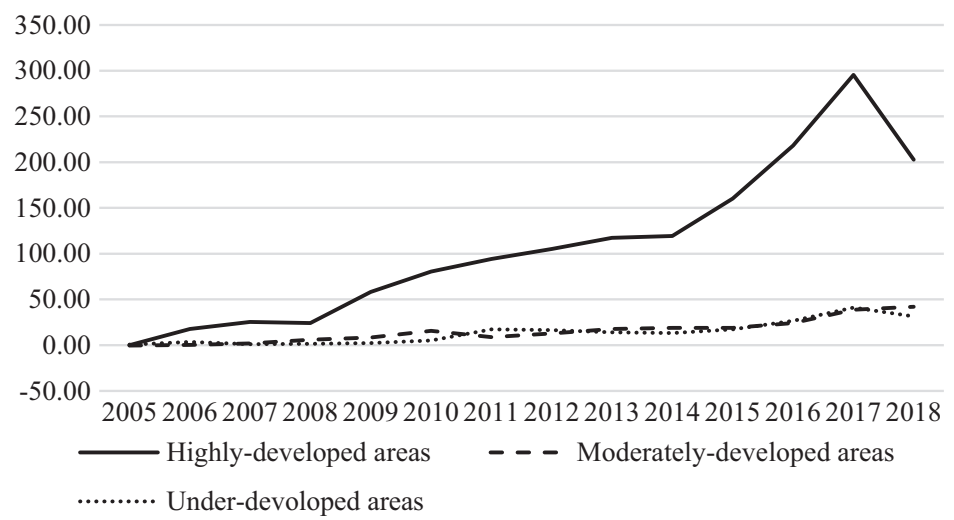

Figure 11.16 Annual net profit of listed family firms by regions (billion yuan).

the improvement in institutional contexts and the embracing of free-market reforms in those regions. Such a result may also be driven by the increasing supply of high-quality human capital, as highly developed areas might attract more and better non-family professionals. Finally, as we discussed above, emerging economic opportunities in highly-developed areas might contribute to performance differences among family firms. Once again, future studies are encouraged to explore the specific reasons behind these findings.

\section{Planning for the future}

In this section, we will discuss issues related to the future of family business in China based on regions, including intra-family, trans-generational succession and social responsibility in family business.

\section{Succession}

The family founder's willingness to pass the business to later-generation family members constitutes a major driving factor behind the succession process. Nonetheless, according to ACFIC data 1997-2010, only about $32 \%$ of family founders are willing to initiate the succession process (Figure 11.17). In fact, in 1997 there was a higher proportion of family founders (42.8\%) who were willing to pass control to their children. This number declined to $24.8 \%$ in 2006 and then increased to $34.1 \%$ in 2010 . The fluctuation might be due to the 2008 financial and economic crisis, which might have suppressed the intention of family succession. In fact, family decision-makers, especially the founder, might choose more conservative ways to pass on the family's wealth, such as through family trusts, financial investments, etc. 


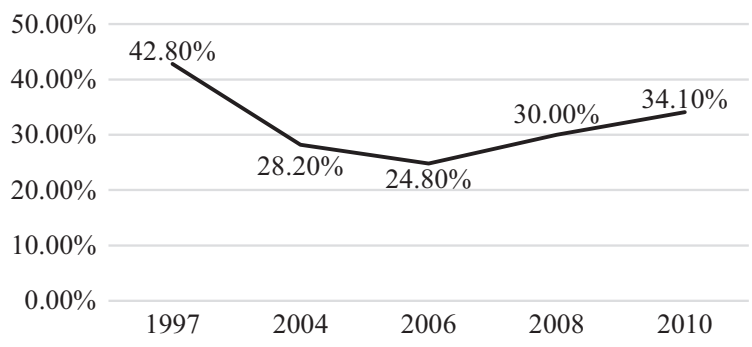

Figure 11.17 Succession intention of entrepreneurs.

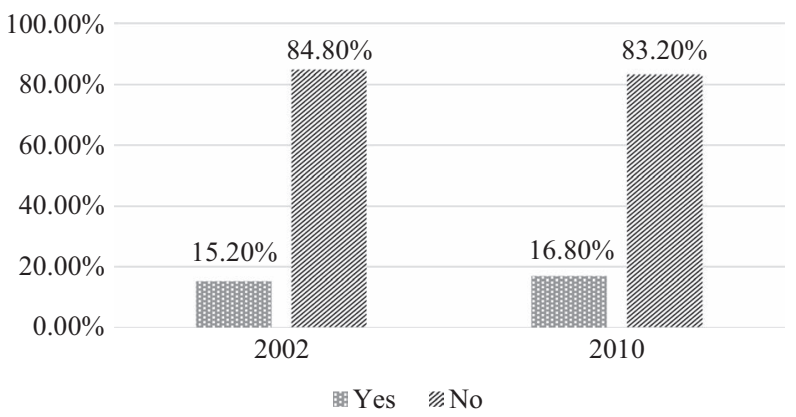

Figure 11.18 Succession intention of the next generation.

The children's willingness to take over the business is also important. According to the survey data in 2002 and 2010 (Figure 11.18), very few late-generation family members were willing to become the successors of the business $(15.2 \%$ in $2002 ; 16.8 \%$ in 2010). This might be because they plan to start their own businesses or because the owning family prefers a more traditional way (i.e., financial investment) to protect the family's wealth.

Even so, according to CSMAR, a large number of second- or latergeneration family members has chosen to work in family firms as chairs, CEOs, top executives, and/or directors. There are certain regional differences (Figure 11.19). The second- or later-generation involvement is highest in moderately-developed regions, followed by highly-developed and underdeveloped regions. As the speed of economic reform varies by regions, the economic opening of less-developed regions was relatively late, which might explain why we have lower later-generation family involvement in less-developed regions. Future researchers can further explore succession issues in Chinese contexts as well as cross-cultural comparisons. For example, what are the unique factors that motivate family founders to initiate the succession process? What factors might enhance the second generation's 


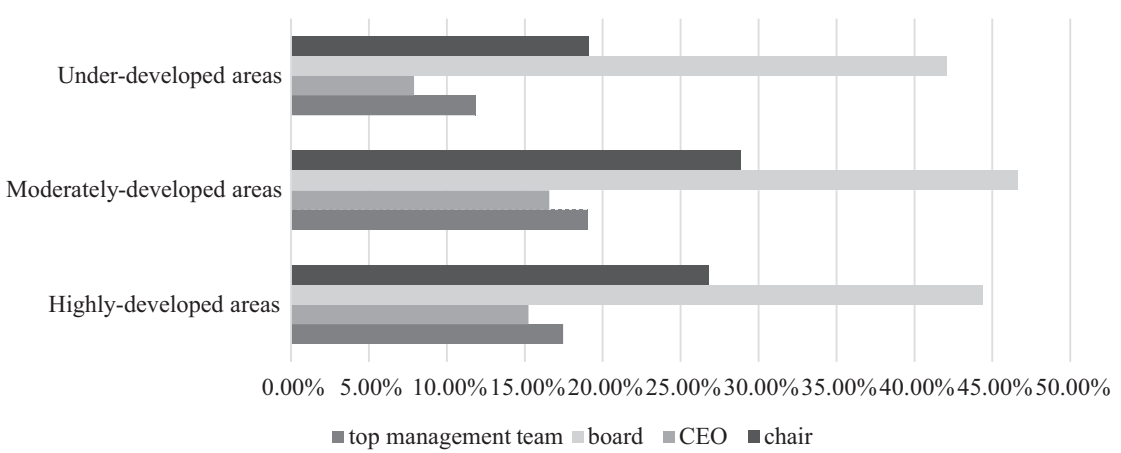

Figure 11.19 Percentage of second or later-generation involvement of listed family firms by regions.

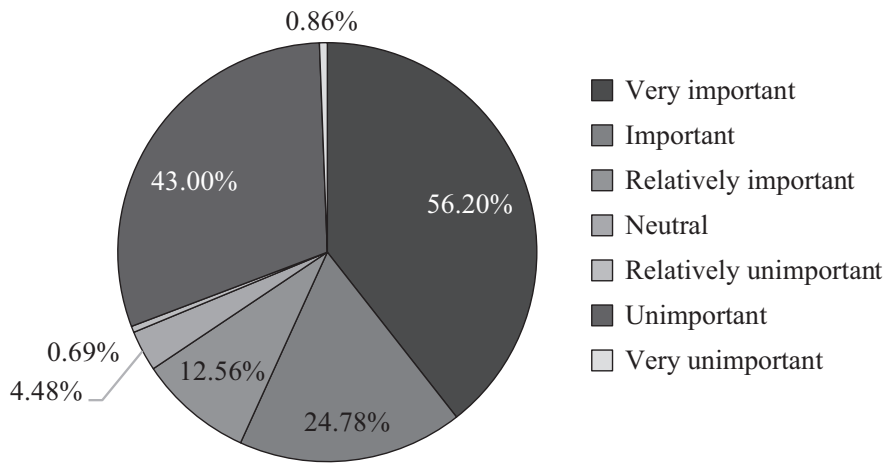

Figure 11.20 CSR in Chinese family firms.

willingness to inherit the business? Affected by frequent changes in political systems and economic policies, entrepreneurs of different ages may have different cognitive models and, hence, we might need more "microfoundation" studies. Indeed, more studies are needed to explore crossindividual, cross-border, and even cross-cultural possibilities.

\section{Corporate social responsibility}

Family firms in China have gradually increased their emphasis on corporate social responsibility (CSR). According to the ACFIC survey (Figure 11.20), $56.2 \%$ of family firms consider CSR very important, $24.78 \%$ important, and $12.56 \%$ relatively important.

According to the China Charity Donation Report, in 2016 there were in total 139.294 billion yuan made in donations, with private family firms 


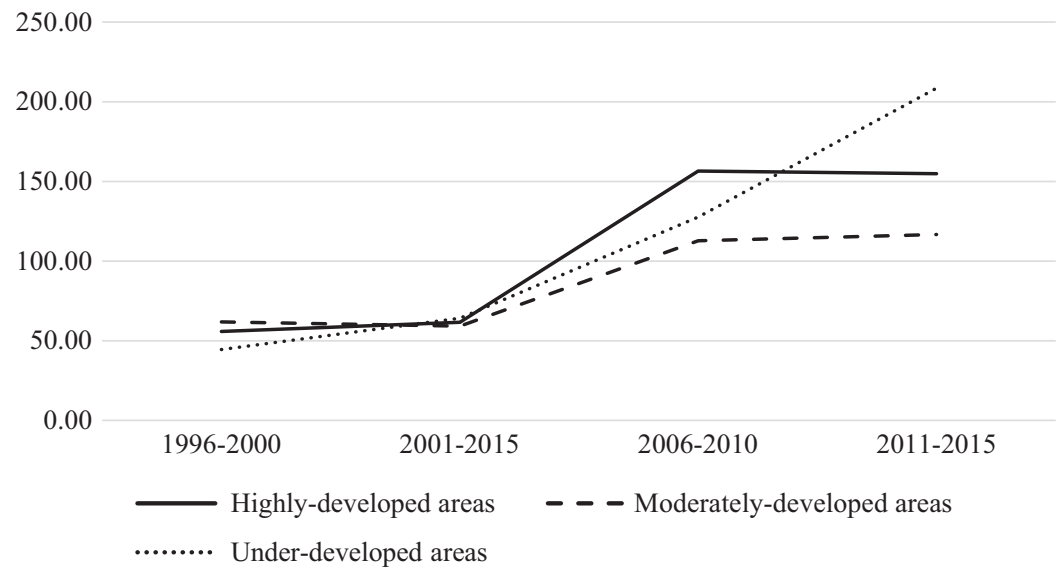

Figure 11.21 Trend of charitable donations made by Chinese private firms in different regions (thousand yuan).

contributing nearly $50 \%$. Figure 11.21 reports the temporal trend in different regions. In general, the annual amount of charity donation has been increasing and the amount in 2015 was almost five times higher than in 1996.

One important part of CSR is the company's intentional effort to reduce damage to the environment and/or propose additional policies to enhance the protection of it. In fact, a large share of the environmental pollution in China is caused by commercial organizations. As the ACFIC survey shows, family firms with 1) better educated family founders, 2) more effective governance mechanisms, and 3) more international operations tend to have heavier investments in environmental protection.

It appears that family firms in under-developed areas have higher environment-related costs (Figure 11.22). This might be because family firms in these areas often pollute more due to weak law enforcement, and higher costs on environmental protection simply reflect the money paid for violations of environment-related laws and regulations. This may reflect the difference in the embeddedness of family firms between regions. Due to data constraints, we cannot explore the relationship between family embeddedness and CSR. Future researchers can collect data in this area for further research. Indeed, whether family firms have more or less CSR has been under debate for a long time (e.g., Campopiano, De Massis, \& Chirico, 2014; Ge \& Micelotta, 2019). Some studies have concluded that family firms might actively engage in CSR activities in order to maintain their family reputation (Campopiano, De Massis, \& Chirico, 2014), whereas some claim that family owners are more "self-interested" and might refuse to invest (Cruz, Larraza-Kintana, Garcés-Galdeano, \& Berrone, 2014). Under the condition of imperfect market competition, CSR of Chinese family firms may stem 


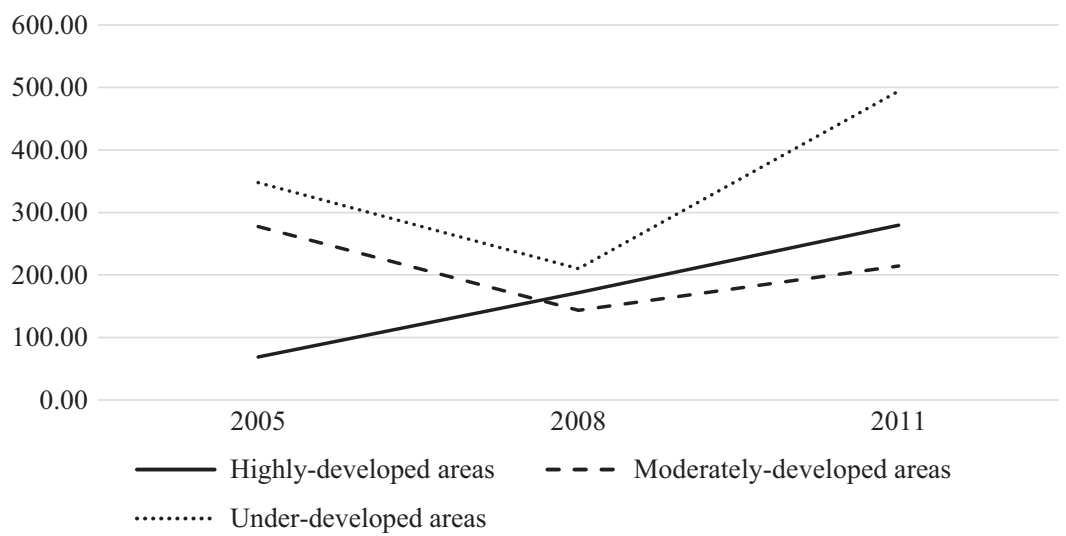

Figure 11.22 Environmental protection costs of private firms in different regions (thousand yuan).

from government pressure. More studies are needed to explore the specific causes of family business CSR in the Chinese context and how these might differ from their Western counterparts.

\section{Discussions}

\section{Theoretical implications}

\section{Comparing to the Western context}

When comparing Chinese family firms with their Western counterparts, we notice many similarities but also some substantial differences. Indeed, business families in China often prefer to have stronger control in ownership, governance, and management than their Western counterparts. This implies that the owning family's power in business is one of the fundamental features in family firms all over the world, in both developed and emerging economies.

In the particular context of China, succession continues to be a critical issue, as second-generation family members often refuse to take a leadership role in business. This lack of motivation might stem from various reasons. For instance, the rise of business opportunities after the 1978 Open-Up and Reform might motivate later generations to start their own businesses rather than succeeding their parents in family firms. In addition, strong dynamics in the institutional and cultural systems might afflict traditional Confucian norms, hence "generational conflict" might be further pronounced in contemporary China, as senior generations often assume traditional values whereas younger ones might place more weight on realizing their individual merits and might refuse to fulfill their family obligations. Of course, the lack 
of motivation among second-generation junior family members may also contribute to the rise of professional non-family management in Chinese family businesses.

\section{Spatial difference and family business in China}

Another issue worth noting is that family firms in China show a high level of heterogeneity, which is largely captured by regional differences. In fact, China is a country with the third-largest national territory in the world. Thus, it represents a unique context to explore the interaction between business families and external factors that result in heterogeneity in family firm behaviors and performances.

As mentioned in the section "The Chinese context, institutional transition, and family entrepreneurs" and throughout the chapter, the similarities and differences can be best explained by the economic, political, and cultural context in China. On one hand, given the long history of the country, power structures and intra-family relationships in business families often reflect the patriarchal traditions rooted in Confucian culture (Fei, Chang, \& Ward, 1946). On the other hand, the free-market system in China remains relatively young and the political and institutional systems are still evolving. Such an issue is reflected in the "unbalanced" distribution across regions, as highly-developed areas might have better institutional context, more economic opportunities, and higher-quality human capital and knowledge resources that family firms can leverage in order to pursue superior firm performance.

As an example, it is found that Chinese family firms located in lessdeveloped regions are less motivated to take risks in strategic actions. It is our suspicion that such regional differences might be related to unbalanced development in institutional and political systems. Indeed, family firms in these regions might be more motivated to develop political connections and make profits from "rent seeking" (Morck \& Yeung, 2004) rather than from the Schumpeterian type of innovation and entrepreneurial activities. It is also found that family firms in highly-developed regions tend to have more revenue from international trade and better firm performance overall, which might stem from the higher prevalence and quality of economic opportunities in these areas. Finally, we notice that family firms in highly-developed regions have stronger control of the business, with more later-generation family members involved as chairs, CEOs, top managers, and directors.

From the summary above, we can conclude that there might be two different types of family firms in China and in other developing and transitional economies according to firm's location: family firms in developed areas and family firms in under-developed areas. This finding seems to suggest that even in one (developing/transitional) economy there still exists a high level of heterogeneity among family firms, largely captured by economic and institutional developments across regions. We encourage future researchers to further explore regional differences based on the characteristics and 
behaviors of family business, as well as factors that might contribute to these differences. Future researchers can further compare this "regional differences" in China with other economies, hence we might be able to develop better understandings of how country-level factors such as culture, economic development, and institutional stability might contribute to regional differences and family firm heterogeneity in each country.

\section{Family business and context}

As entrepreneurship literature and the theory of endogenous development remind us (e.g., Audretsch \& Keilbach, 2004; Feldman, 2001), entrepreneurs and business persons are adaptive agents who often actively adjust their strategies to best capture opportunities and neutralize threats stemming from the context, reflected in policies, financing, labor, and other aspects (Acs \& Varga, 2005; Black, Meza, \& Jeffreys, 1996; Johnson \& Parker, 1996). While arguably both family and non-family firms are affected by context, the uniqueness of family businesses lies in its deeper "embeddedness" in the local community through family-centered and/or family-member-based business connections and social relations (Basco, 2015). Such a high embeddedness might imply that, compared to their non-family counterparts, family firms might be more "altered" to valuable information from the context, hence are more "adaptive" as they are able to better and more quickly identify upcoming opportunities and threats in the context. Another important insight is that, given an upcoming opportunity or threat, the strong family-centered control in business can ensure that business families are capable of responding more quickly without the interference from other decision-makers. That means that not only can family firms better identify unusual signals in the context, but that they are also capable of responding even more quickly than non-family firms.

\section{Practical implications}

This chapter has some practical implications for designing government policies and nurturing next-generation family leaders. To begin, economic development not only depends on the stock of capital, also on who owns and uses the capital (Morck \& Yeung, 1998). As mentioned above, family businesses and business families have been playing an important role in China's economic development. Indeed, given the strong focus on "family" in the traditional Confucian culture, as well as the prevalence of family firms in all regions, federal and local governments in China should maintain a high degree of tolerance for family businesses and create an environment that is conducive to business families.

Given substantial regional differences, local governments should design specific family business-related policies that fit local context. For underdeveloped regions, it might be important for local governments to increase 
transparency and reduce the costs of accessing and obtaining external resources. In another word, local governments should find alternative measures to "substitute" political connections and establish a more mature market system, so that the competitiveness of local family firms can be further improved. Under such circumstances, local governments should open more channels to communicate with family firms, and provide them with more support in terms of expertise, infrastructure, and debt financing. Similar measures have been implemented in large and more-developed cities such as Beijing, Shanghai, Guangzhou, Shenzhen, and others.

It is important to note that, according to the ACFIC survey, most second-generation family members refuse to take the leadership role in family businesses partially due to the explosion of entrepreneurial opportunities and their ambition to start their own businesses. Given such a context, it is important for the government to develop specific policies, such as those highlighting family tradition and the legacy of family founders, in order to prepare future generations for assuming the leadership transfer.

Indeed, second- or later-generation family members grew up during a period of great social change in China and might possess a completely different mentality compared to their parents. Furthermore, the educational background of the leadership seems to be important even in the family business context. Hence, local governments need to design policies to motivate second-generation family members to be more actively involved in their family firms and design educational systems that nurture these junior family members such that their knowledge and skill structures can match severe market competition.

\section{Limitations}

There are limitations to the analysis conducted in this chapter, which might shed light on future studies of Chinese family firms. First, we report our findings based on two databases: the China Stock Market \& Accounting Research Databases (CSMAR) public database and the All-China Federation of Industry and Commerce (ACFIC) database. While these two cover both publicly-traded and private family firms, future researchers might want to use alternate databases, especially those with broader coverage of family systems and members to better explore family business and regional development in China.

Second, although we intend to compare Chinese family firms with their Western counterparts, the two databases we used do not contain any information related to family firms in other economies. Future researchers might want to develop some comparative studies with a focus on how the respective economic and institutional contexts of China and Western countries might contribute to the similarities and differences of family firms in these regions. 
Finally, it is important to note that our discussion is bounded by a lack of historical longitudinal data. In fact, CSMAR started to include family business data just a few years ago, ACFIC's earliest survey data is from 1995, and even data related to private firms offered by the National Bureau of Statistics of China only started from 1999. Future researchers might want to collect richer historical data, especially those related to family businesses before and after the Opening-Up and Reform era that started in 1978.

\section{References}

Acs, Z. J., \& Varga, A. (2005). Entrepreneurship, agglomeration and technological change. Small Business Economics, 24(3), 323-334.

Aldrich, H. E., \& Cliff, J. E. (2003). The pervasive effects of family on entrepreneurship: Toward a family embeddedness perspective. Journal of Business Venturing, 18(5), 573-596.

Arregle, J., Hitt, M. A., Sirmon, D. G., \& Very, P. (2007). The development of organizational social capital: Attributes of family firms. Journal of Management Studies, 44(1), 73-95.

Audretsch, D., \& Keilbach, M. (2004). Entrepreneurship capital and economic performance. Regional Studies, 38(8), 949-959.

Baker, H. B. (1979). Chinese Family and Kinship. New York: Columbia University Press.

Basco, R. (2015). Family business and regional development - A theoretical model of regional familiness. Journal of Family Business Strategy, 6(4), 259-271.

Basco, R. (2018). Family business in emerging economies. In R. Grosse \& K. Meyer (Eds.), Oxford Handbook on Management in Emerging Markets (pp. 527-546). Oxford: Oxford University Press.

Black, J., Meza, D. D., \& Jeffreys, D. (1996). House prices, the supply of collateral and the enterprise economy. The Economic Journal, 106(434), 60-75.

Carney, M. (1998). A management capacity constraint? Obstacles to the development of the overseas Chinese family business. Asia Pacific Journal of Management, 15(2), 137-162.

Carney, M. (2005). Corporate governance and competitive advantage in familyowned firms. Entrepreneurship Theory and Practice, 29(3), 249-266.

Campopiano, G., De Massis, A., \& Chirico, F. (2014). Firm philanthropy in smalland medium-sized family firms. Family Business Review, 27(3), 244-258.

Chen, S., Fang, H. C., MacKenzie, N. G., Carter, S., Chen, L., \& Wu, B. (2018). Female leadership in contemporary Chinese family firms. Asia Pacific Journal of Management, 35(1), 181-211.

Chrisman, J. J., Chua, J. H., Kellermanns, F. W., \& Chang, E. (2007). Are family managers agents or stewards? An exploratory study in privately held family firms. Journal of Business Research, 60(10), 1030-1038.

Chua, J. H., Chrisman, J. J., \& Sharma, P. (1999). Defining the family business by behavior. Entrepreneurship Theory and Practice, 23(4), 19-39.

Chua, J. H., Chrisman, J. J., \& Sharma, P. (2003). Succession and nonsuccession concerns of family firms and agency relationship with nonfamily managers. Family Business Review, 16(2), 89-107. 
Cruz, C., Larraza-Kintana, M., Garcés-Galdeano, L., \& Berrone, P. (2014). Are family firms really more socially responsible? Entrepreneurship Theory and Practice, 38(6), 1295-1316.

Curimbaba, F. (2002). The dynamics of women's roles as family business managers. Family Business Review, 15(3), 239-252.

De Massis, A., Ding, S., Kotlar, J., \& Wu, Z. (2016). Family involvement and R\&D expenses in the context of weak property rights protection: An examination of non-state-owned listed companies in China. The European Journal of Finance, 24(16), 1506-1527.

De Massis, A., Frattini, F., \& Lichtenthaler, U. (2012). Research on technological innovation in family firms: Present debates and future directions. Family Business Review, 26(1), 10-31.

Faccio, M. (2006). Politically connected firms. American Economic Review, 96(1), 369-386.

Fang, H., Kotlar, J., Memili, E., Chrisman, J. J., \& De Massis, A. (2018). The pursuit of international opportunities in family firms: Generational differences and the role of knowledge-based resources. Global Strategy Journal, 8(1), 136-157.

Feldman, M. P. (2001). The entrepreneurial event revisited: Firm formation in a regional context. Industrial and Corporate Change, 10(4), 861-891.

Fei, H. T. U., Chang, C. I., \& Ward, R. F. (1946). Earthbound China: A Study of Rural Economy in Yunnan. Chicago, IL: University of Chicago Press.

Ge, J., \& Micelotta, E. (2019). When does the family matter? Institutional pressures and corporate philanthropy in China. Organization Studies, 40(6), 833-857.

Gollop, F. M., \& Monahan, J. L. (1991). A generalized index of diversification: Trends in U.S. manufacturing. The Review of Economics and Statistics, 73(2), 318.

James, A. E., Hadjielias, E., Guerrero, M., Discua Cruz, A., \& Basco, R. (2020). Entrepreneurial families in business across generations, context, and cultures. Journal of Family Business Management, forthcoming. doi:10.1108/CCSM-02-2020-223

Janjuha-Jivraj, S., \& Woods, A. (2002). Successional issues within Asian family firms: Learning from the Kenyan experience. International Small Business Journal, 20(1), 77-94.

La Porta, R., Lopez-de-Silanes, F., \& Shleifer, A. (1999). Corporate ownership around the world. The Journal of Finance, 54(2), 471-517.

Li, H., \& Zhang, Y. (2007). The role of managers' political networking and functional experience in new venture performance: Evidence from China's transition economy. Strategic Management Journal, 28(8), 791-804.

Li, W., He, A., Lan, H., \& Yiu, D. (2011). Political connections and corporate diversification in emerging economies: Evidence from China. Asia Pacific Journal of Management, 29(3), 799-818.

Liden, R. C. (2012). Leadership research in Asia: A brief assessment and suggestions for the future. Asia Pacific Journal of Management, 29(2), 205-212.

Gomez-Mejia, L. R., Basco, R., Müller, C., \& Gonzalez, A. C. (2020). Family business and local development in Iberoamerica. Cross-Cultural Management Journal, 27(2), 121-136.

Jacquemin, A. P., \& Berry, C. H. (1979). Entropy measure of diversification and corporate growth. The Journal of Industrial Economics, 27(4), 359.

Johnson, P., \& Parker, S. (1996). Spatial variations in the determinants and effects of firm births and deaths. Regional Studies, 30(7), 679-688. 


\section{Xinrui Zhang et al.}

Jones, G. R., \& Hill, C. W. (1988). Transaction cost analysis of strategy-structure choice. Strategic Management Journal, 9(2), 159-172.

Memili, E., Fang, H., \& Welsh, D. H. (2015). Value creation and value appropriation in innovation process in publicly-traded family firms. Management Decision, 53(9), 1921-1952.

Morck, R., \& Steier, L. (2005). The global history of corporate governance: An introduction. In R. Morck (Ed.), A History of Corporate Governance around the World: Family Business Groups to Professional Managers (pp. 1-64). Chicago, IL: University of Chicago Press.

Morck, R. K., Stangeland, D. A., \& Yeung, B. (1998). Inherited wealth, corporate control and economic growth: The Canadian disease? National Bureau of Economic Research Working Paper Series. Retrieved form https://www.nber.org/ papers/w6814.pdf

Morck, R. K., \& Yeung, B. (2004). Family control and the rent-seeking society. Entrepreneurship Theory and Practice, 28(4), 391-410.

Morris, M. H., Allen, J. A., Kuratko, D. F., \& Brannon, D. (2010). Experiencing family business creation: Differences between founders, nonfamily managers, and founders of nonfamily firms. Entrepreneurship Theory and Practice, 34(6), $1057-1084$.

Nelton, S. (1998). The rise of women in family firms: A call for research now. Family Business Review, 11, 215-218.

Peng, M. W., \& Luo, Y. (2000). Managerial ties and firm performance in a transition economy: The nature of a micro-macro link. Academy of Management Journal, 43(3), 486-501.

Peng, M. W., Lee, S.-H., \& Wang, D. Y. L. (2005). What determines the scope of the firm over time? A focus on institutional relatedness. Academy of Management Review, 30(3), 622-633.

Pistrui, D., Huang, W., Oksoy, D., Jing, Z., \& Welsch, H. (2001). Entrepreneurship in China: Characteristics, attributes, and family forces shaping the emerging private sector. Family Business Review, 14(2), 141-152.

Sharma, P., \& Chua, J. H. (2013). Asian family enterprises and family business research. Asia Pacific Journal of Management, 30(3), 641-656.

Tsang, E. W. (1996). In search of legitimacy: The private entrepreneur in China. Entrepreneurship Theory and Practice, 21(1), 21-30.

Xu, N., Xu, X., \& Yuan, Q. (2013). Political connections, financing friction, and corporate investment: Evidence from Chinese listed family firms. European Financial Management, 19(4), 675-702. 